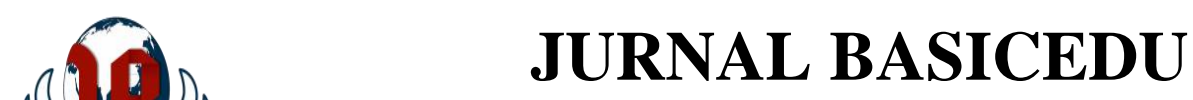

Volume 5 Nomor 3 Tahun 2021 Halaman 1377-1389

Research \& Learning in Elementary Education https://jbasic.org/index.php/basicedu

\author{
-
}

\title{
Upaya Meningkatkan Kualitas Pembelajaran Matematika Geometri dengan Menggunakan Pembelajaran Kooperatif Tipe STAD di MIN Kota Jambi
}

\author{
Sopiah \\ Madrasah Ibtidaiyah Negeri Kota Jambi, Indonesia \\ E-mail: sopiahshp09@gmail.com
}

\begin{abstract}
Abstrak
Guru masih menekankan metode ceramah dan latihan siap dalam penyampaian materi. Para siswa cenderung pasif karena mendengarkan penjelasan guru, mengerjakan soal dan mengikuti pembahasan soal sehingga pembelajaran Matematika praktis masih berpusat pada guru. Tujuan dari penelitian ini adalah untuk: 1) Mendeskripsikan peningkatkan keterampilan guru dalam pembelajaran matematika materi geometri dengan menggunakan pembelajaran kooperatif tipe STAD. 2) Mendeskripsikan peningkatkan minat siswa dalam pembelajaran matematika materi geometri dengan menggunakan pembelajaran kooperatif tipe STAD. 3) meningkatkan hasil belajar siswa dalam pembelajaran matematika materi geometri dengan menggunakan pembelajaran kooperatif tipe STAD. Metode penelitian tindakan kelas merupakan suatu rangkaian pelaksanaan empat tahapan penting yang harus berulang pada tiap siklus. tahapan penting dalam penelitian tindakan kelas: 1) perencanaan, 2) pelaksanaan tindakan, (3) pengamatan dan (4) refleksi. Rata-rata hasil belajar siswa dalam pembelajaran geometri melalui pembelajaran kooperatif tipe $S T A D$, mengalami peningkatan. Rata-rata nilai siswa meningkat dari siklus I sebesar 61,56 menjadi 69,22 pada siklus II. Persentase ketuntasan belajar individual siswa juga mengalami peningkatan dari $64 \%$ atau 20 dari 32 siswa pada siklus I menjadi $77 \%$ atau 25 dari 32 siswa pada siklus II. Berdasarkan data tersebut, pencapaian hasil belajar siswa pada siklus kedua sudah mencapai indikator keberhasilan yaitu 75\% siswa mengalami ketuntasan belajar individual $\geq 60$.
\end{abstract}

Kata Kunci: Kualitas Pembelajaran, matematika, kooperatif stand.

\begin{abstract}
Teachers still emphasize lecture method and giving exercises in the learning proccess. Students tend to be passive because they listen to the teacher's explanation, work on exercises and follow the discussion of exercises solving so that practical Mathematics learning is still teacher-centered. The objectives of this study are to: 1) describe the improvement of teachers' skills in mathematics learning for geometry material using cooperative learning type $S T A D, 2)$ describe the increase of students' interest in mathematics learning for geometry material using cooperative learning type STAD, and 3) improve students' learning outcomes in mathematics learning for geometry material by using cooperative learning type STAD. The classroom action research method is a series of implementation of four important stages that must be repeated in each cycle. Important stages in classroom action research: 1) planning, 2) implementing the action, (3) observation and (4) reflection. The average of students' learning outcomes in learning geometry through cooperative learning type STAD have increased. The average score of students increased from the first cycle of 61.56 to 69.22 in the second cycle. The percentage of students' individual learning completeness also increased from $64 \%$ or 20 of 32 students in cycle I to $77 \%$ or 25 of 32 students in cycle II. Based on these data, students' learning outcomes in the second cycle has reached an indicator of success, namely $75 \%$ of students reach individual learning completeness $\geq 60$.
\end{abstract}

Keywords: Learning Quality, mathematics, cooperative stad.

Copyright (c) 2021 Sopiah

Corresponding author :

Email : sopiahshp09@gmail.com

DOI : $:$ https://doi.org/10.31004/basicedu.v5i3.929 
1378 Upaya Meningkatkan Kualitas Pembelajaran Matematika Materi Geometri dengan Menggunakan Pembelajaran Kooperatif Tipe STAD di MIN Kota Jambi-Sopiah

DOI : https://doi.org/10.31004/basicedu.v5i3.929

\section{PENDAHULUAN}

Proses pembelajaran yang menarik dan memberikan kesan serta pengalaman secara langsung, sesuai dengan kehidupan dan kebutuhan aktual siswa ialah proses pembelajaran yang diharapkan saat ini. Kurikulum memberikan banyak peluang kepada sekolah dan guru untuk menciptakan pembelajaran yang sesuai dengan kebutuhan siswa di sekolahnya (Boliti, 2009).

Sejauh ini pendidikan masih didominasi oleh pandangan bahwa pengetahuan sebagai perangkat faktafakta yang harus dihafal. Kelas masih berfokus pada guru sebagai sumber utama pengetahuan, kemudian ceramah menjadi pilihan utama strategi belajar. Oleh karena itu, diperlukan sebuah strategi belajar baru yang lebih memberdayakan siswa. Sebuah strategi belajar yang tidak mengharuskan siswa menghafal fakta-fakta, tetapi sebuah strategi yang mendorong siswa mengonstruksikan pengetahuan dibenak mereka sendiri.

Rendahnya kualitas pembelajaran matematika di Indonesia tidak terlepas dari faktor guru dan faktor siswa. Guru dalam sebagian besar pembelajarannya masih konvensional dan metode kurang bervariasi (Jamaluddin, 2020). Pembelajaran masih menekankan pada latihan mengerjakan soal atau drill and pactice (Dewi et al., 2021), serta masih didominasi oleh penggunaan metode ceramah (verbalistik) dan peran guru (teacher centered).

Hal tersebut membuat pembelajaran monoton sehingga siswa merasa jenuh dan tersiksa (Fakhri et al., 2020). Adapun faktor yang memengaruhi kualitas pembelajaran matematika yang berasal dari siswa adalah minat belajar siswa yang masih rendah dalam pembelajaran matematika. (Khotimah \& Sari, 2018) berpendapat rendahnya prestasi siswa dan kurangnya minat siswa dalam belajar matematika merupakan dua masalah utama dalam pendidikan matematika di Indonesia. Selain itu, siswa tidak terlatih untuk mengemukakan pendapat, berinteraksi dan bekerjasama dalam belajar sehingga memunculkan kesenjangan nilai antara siswa yang pandai dengan siswa yang kurang atau bahkan tidak pandai (Syarif Sumantri \& Satriani, 2016). Kondisi serupa juga terjadi dalam pembelajaran di kelas IV di MIN Kota Jambi.

Berdasarkan refleksi bersama tim kolaborasi terhadap hasil pengamatan dan dokumen hasil pembelajaran diketahui bahwa guru kurang inovatif dalam pembelajaran Matematika (Sodiq \& Trisniawati, 2020). Guru masih menekankan penggunaan metode ceramah dan latihan siap (drill) dalam penyampaian materi. Para siswa cenderung pasif karena hanya mendengarkan penjelasan guru, mengerjakan soal dan mengikuti pembahasan soal sehingga pembelajaran Matematika praktis masih berpusat pada guru (teacher centered).

Meskipun ada sebagian siswa yang dapat mengikuti pembelajaran secara aktif dengan bertanya dan berdiskusi, tetapi kegiatan itu didominasi oleh siswa-siswa yang tergolong pandai saja. Para siswa yang tergolong pandai belum mampu membantu para siswa lain yang kurang pandai untuk belajar dengan baik sehingga terjadi kesenjangan antara nilai hasil belajar siswa yang tergolong pandai dengan siswa yang tergolong kurang pandai. Kondisi tersebut bertambah parah dengan kurangnya minat siswa terhadap pembelajaran Matematika (Fadhilaturrahmi, 2017). Salah satu indikator siswa tidak berminat dalam pembelajaran matematika adalah siswa cenderung pasif pada saat pembelajaran serta kurangnya kerjasama dan interaksi siswa dalam membahas materi Matematika yang sedang diajarkan.

Rendahnya kualitas pembelajaran matematika di kelas IV MIN Kota Jambi , juga dapat dilihat dari data hasil penilaian Ulangan Akhir Semester I (UAS I) kelas IV tahun pelajaran 2018/2019. Dengan KKM 60, siswa yang memperoleh nilai tuntas $K K M 60$ adalah 8 siswa $(22,86 \%)$ dari total 35 siswa, sedangkan sisanya yaitu 27 siswa $(77,14 \%)$ tidak tuntas. Keadaan lebih spesifik dapat dilihat dari data ulangan harian matematika materi geometri. Dari 35 siswa yang mengikuti ulangan dengan $K K M 60$, terdapat 10 siswa yang tuntas (28,57\%), sedangkan sisanya yaitu 25 siswa (71,43\%) tidak tuntas. Kondisi ini ditambah dengan adanya kesenjangan nilai diantara siswa, yaitu dengan nilai terendah siswa 20 dan nilai tertinggi siswa 88,5 dengan rata-rata nilai 37,43 . 
1379 Upaya Meningkatkan Kualitas Pembelajaran Matematika Materi Geometri dengan Menggunakan Pembelajaran Kooperatif Tipe STAD di MIN Kota Jambi-Sopiah

DOI : https://doi.org/10.31004/basicedu.v5i3.929

Keadaan tersebut perlu segera diperbaiki mengingat pentingnya tiap tahapan pembelajaran matematika yang bersifat berkesinambungan dan mendukung antarkonsep pada materi yang satu deng an materi yang lain. Sehingga dibutuhkan penanganan secara tepat untuk mengatasi permasalahan tersebut. Bagi siswa MIN, pembelajaran menjadi lebih bermakna ketika dimulai dari hal yang konkret, menarik dan dilakukan dalam suatu interaksi sosial sesuai dengan tahapan perkembangan intelektualnya. Siswa sekolah dasar perlu belajar dalam lingkungan sosialnya yang berupa kelompok-kelompok untuk saling berinteraksi, saling mengisi dan melengkapi (Lin et al., 2020).

Pembelajaran yang disajikan juga perlu disajikan dalam model pembelajaran yang tepat. Model pembelajaran memiliki peranan yang penting sebagai cara menyajikan atau mengemas pembelajaran. Selain model pembelajaran yang tepat, pembelajaran juga harus sesuai dengan karakteristik siswa sekolah dasar yang masih memerlukan lingkungan sosialnya untuk saling berinteraksi, saling mengisi dan melengkapi (Syarif Sumantri \& Satriani, 2016). Oleh karena itu, upaya perbaikan pembelajaran matematika di kelas IV MIN Kota Jambi dilakukan dengan menerapkan model pembelajaran kooperatif. Pembelajaran kooperatif adalah pembelajaran yang dilakukan dengan cara mengelompokkan siswa kedalam kelompok-kelompok kecil untuk saling bekerjasama dengan prinsip mempelajari sesuatu sebagai sebuah tim dengan difasilitasi oleh guru (Kamil \& Kashardi, 2020).

Berdasarkan latar belakang tersebut, peneliti tertarik untuk berusaha meningkatkan kualitas pembelajaran matematika khususnya materi geometri pokok bahasan bagun ruang sederhana di kelas IV dengan melakukan penelitian dengan judul "Upaya Meningkatkan Kualitas Pembelajaran Matematika Materi Geometri dengan Menggunakan Model Pembelajaran Kooperatif Tipe STAD di MIN Kota Jambi.

Tujuan dari penelitian ini adalah untuk: 1) Mendeskripsikan peningkatkan keterampilan guru dalam pembelajaran matematika materi geometri dengan menggunakan pembelajaran kooperatif tipe STAD. 2) Mendeskripsikan peningkatkan minat siswa dalam pembelajaran matematika materi geometri dengan menggunakan pembelajaran kooperatif tipe STAD. 3) meningkatkan hasil belajar siswa dalam pembelajaran matematika materi geometri dengan menggunakan pembelajaran kooperatif tipe $S T A D$.

\section{METODE PENELITIAN}

(Hendrayani, 2018) penelitian tindakan kelas pada umumnya merupakan suatu rangkaian pelaksanaan empat tahapan penting yang harus ber-ulang pada tiap siklus. Empat tahapan penting dalam penelitian tindakan kelas adalah (1) perencanaan (planning), (2) pelaksanaan tindakan (acting), (3) peng-amatan (observing) dan (4) refleksi (reflecting).

Subjek penelitian ini adalah siswa kelas IV MIN Kota Jambi Semester II Tahun Pelajaran 2019/2020. Subjek tersebut berjumlah 32 siswa yang terdiri dari 11 siswa laki-laki dan 21 siswa perempuan. Penelitian ini dilaksanakan di MIN Kota Jambi.

Data-data yang diambil dalam penelitian ini dapat digolongkan menjadi data kuantitatif dan data kualitatif. Data kuantitatif dalam penelitian ini berupa hasil belajar siswa kelas IV Madrasah Ibtidaiyah Negeri Kota Jambi pada mata pelajaran Matematika. Sedangkan data kualitatif berupa hasil observasi minat siswa yang dimanifestasikan dalam bentuk aktivitas siswa yang terjadi karena penerapan model pembelajaran kooperatif tipe $S T A D$, serta keterampilan guru dalam mengelola pembelajaran Matematika dengan menggunakan model pembelajaran kooperatif tipe $S T A D$. Alat pengumpulan dan teknik pengumpulan data dalam penelitian ini menggunakan tes, angket, pedoman observasi dan dokumentasi. Data-data yang dikumpulkan kemudian dianalisis menggunakan teknik kuantitatif dan teknik kualitatif sesuai dengan jenis datanya. 
1380 Upaya Meningkatkan Kualitas Pembelajaran Matematika Materi Geometri dengan Menggunakan Pembelajaran Kooperatif Tipe STAD di MIN Kota Jambi-Sopiah

DOI : https://doi.org/10.31004/basicedu.v5i3.929

\section{HASIL DAN PEMBAHASAN}

Hasil penelitian ini didapat dari hasil penilaian tes dan nontes. Hasil tersebut merupakan perolehan data pelaksanaan penelitian selama dua siklus, yaitu siklus I dan siklus II. Hasil tes kedua siklus tersebut berupa tes formatif yang dilaksanakan disetiap akhir siklus untuk mengukur pemahaman dan penguasaan konsep Matematika siswa tentang materi geometri melalui Kooperatif tipe STAD dalam bentuk data kuantitatif. Hasil non tes siklus I dan siklus II berupa hasil pengamatan, dokumentasi foto pada saat berlangsungnya pembelajaran dan angket minat siswapada pembelajaran Matematika menggunakan pembelajaran koopeartif tipe $S T A D$ yang disajikan dalam bentuk deskripsi dan data kualitatif.

Penelitian ini dimulai dengan kegiatan prasiklus yaitu mengambil data angket siswa kelas IV MIN Kota Jambi, kemudian pelaksanaan siklus I, dan pelaksanaan siklus II. Deskripsi hasil pelaksanaan tiap siklus adalah sebagai berikut: Siklus I dilaksanakan dalam dua pertemuan. Hasil pelaksanaannya dapat dijelaskan perpertemuan sebagai berikut: 1) Diskripsi observasi pelaksanaan tindakan siklus I pertemuan 1 terdiri dari hasil observasi keterampilan guru, hasil observasi manifestasi minat siswa dan hasil belajar siswa. Hasil siklus I pertemuan 1 dijelaskan sebagai berikut: Peneliti melakukan observasi pada saat pembelajaran sedang berlangsung, terutama pada saat melakukan pembimbingan kelompok. Hal tersebut peneliti lakukan untuk mendapatkan data yang berkenaan dengan minat siswa dalam proses pembelajaran Matematika materi geometri melalui model pembelajaran kooperatif tipe STAD. Minat siswa dalam proses pembelajaran Matematika materi geometri me-lalui model pembelajaran kooperatif tipe STAD pada siklus I pertemuan 1, dapat dilihat dari hasil observasi manifestasi minat siswa pada pembelajaran matematika materi geometri melalui pembelajaran kooperatif tipe $S T A D$. Data yang diperoleh berupa data kualitatif.

Dari data observasi minat siswa siklus I pertemuan 1 pada pembelajaran Matematika materi geometri melalui pembelajaran kooperatif tipe $S T A D$, Pada indikator mempersiapkan diri dalam pembelajaran, dua siswa men-dapatkan skor 1, empat siswa mendapatkan skor 2, sepuluh siswa mendapatkan skor 3 dan enam siswa mendapatkan skor 4. Dengan keadaan tersebut, jumlah skor menjadi 84 dan rata-rata 2,63 sehingga tergolong dalam kategori berminat. Untuk indikator menanggapi apersepsi guru, siswa tergolong dalam kategori cukup berminat. Hal tersebut karena enam siswa mendapatkan skor 1, sembilan belas siswa mendapatkan skor 2, tujuh siswa mendapatkan skor 3 dan tidak ada siswa yang mendapatkan skor 4 , sehingga jumlah skor hanya 65 dengan rata-rata 2,03. Adapun indikator konsentrasi menerima penjelasan guru, siswa yang memperoleh skor 1 sebanyak dua siswa, skor 2 diperoleh sepuluh siswa, skor 3 diperoleh enam belas siswa dan skor 4 diperoleh empat siswa. Jumlah skor 86 dengan rata-rata 2,69 dan tergolong dalam kategori berminat.

Indikator berinisiatif menanyakan sesuatu yang belum dipahami memperoleh skor terendah, karena hanya mendapatkan skor dengan jumlah 61 dengan rata-rata 1,91 dan tergolong cukup berminat. Hal tersebut karena lima belas siswa mendapatkan skor 1, delapan siswa mendapatkan skor 2, enam siswa mendapatkan skor 3 dan hanya tiga siswa yang mendapatkan skor 4 . Keadaan ini mengindikasikan bahwa minat siswa masih perlu ditingkatkan, terutama dalam bertanya dan mengemukakan pendapat.

Segera melaksanakan tugas dalam pembentukan kelompok merupakan indikator berikutnya yang siswa tergolong berminat didalamnya. Hal tersebut karena siswa yang mendapatkan skor 4 sebanyak enam belas siswa, delapan siswa mendapatkan skor 3, empat siswa mendapatkan skor 2 dan empat siswa yang lain mendapat skor 1, sehingga jumlah skor 100 dan rata-rata skor 3,13. Untuk indikator dapat bekerjasama dalam kelompok, siswa tergolong berminat, terbukti dengan skor 4 diperoleh oleh dua belas siswa, skor 3 diperoleh oleh sepuluh siswa, skor 2 diperoleh oleh delapan siswa dan skor 1 diperoleh hanya oleh dua siswa, sehingga jumlah skor 96 dan rata-rata 3,0. Bekerja keras dalam mengerjakan tugas kelompok merupakan indikator yang siswa tergolong berminat selanjutnya. Siswa yang memperoleh skor 4 adalah enam belas siswa, dua belas siswa memperoleh skor 3, empat siswa memperoleh skor 2 dan dua siswa memperoleh skor 1 dengan perolehan skor 110 dan rata-rata 3,44. Teratur dalam mengerjakan evaluasi merupakan indikator yang 
1381 Upaya Meningkatkan Kualitas Pembelajaran Matematika Materi Geometri dengan Menggunakan Pembelajaran Kooperatif Tipe STAD di MIN Kota Jambi-Sopiah

DOI : https://doi.org/10.31004/basicedu.v5i3.929

mendapatkan skor tertinggi yaitu jumlah skor 116 dengan rata-rata 3,63 dan masih tergolong dalam kategori berminat. Skor tersebut diperoleh oleh dua puluh dua siswa yang mendapatkan skor 4, delapan siswa mendapatkan skor 3, dua siswa mendapatkan skor 2 dan tidak ada siswa yang mendapatkan skor 1 .

Untuk indikator tertib dalam menerima penghargaan kelompok, siswa yang mendapatkan skor 1 adalah empat siswa, skor 2 diperoleh enam siswa, skor 3 diperoleh dua puluh siswa dan skor 4 diperoleh dua siswa dengan jumlah 84 dan rata-rata 2,63. Dengan hasil tersebut, siswa tergolong berminat. Menanggapi umpan balik dari guru sebagai bahan refleksi adalah indikator terakhir yang siswa tergolong berminat didalamnya. Hal tersebut terjadi karena ada dua siswa yang memperoleh skor 1, delapan siswa memperoleh skor 2, enam belas siswa memperoleh skor 3 dan enam siswa memperoleh skor 4 sehingga jumlah skor 90 dan rata-rata 2,81 .

Hasil belajar siswa dalam pembelajaran Matematika materi geometri me-lalui pembelajaran kooperatif tipe STAD diperoleh dari hasil post tes pada pem-belajaran siklus I pertemuan 1. Post tes tersebut dilaksanakan dalam bentuk pilihan ganda yang terdiri dari sepuluh soal dengan skor maksimal seratus. Data hasil belajar siswa pada siklus I pertemuan 1 dapat diketahui bahwa nilai tertinggi yang diperoleh siswa adalah 100 dan nilai terendah adalah 20 dengan rata-rata 60,00. Persentase ketuntasan hasil belajar siswa adalah 59\% yaitu diperoleh oleh 19 siswa, sedangkan persentase ketidaktuntasan hasil belajar siswa adalah $41 \%$ yang diperoleh oleh 13 siswa.

Refleksi pembelajaran geometri melalui model pembelajaran kooperatif tipe STAD pada siklus I pertemuan 1 difokuskan pada tiga hal, yaitu: keterampilan guru, manifestasi minat siswa dan hasil belajar.

Refleksi ini dipergunakan sebagai bahan pertimbangan untuk memperbaiki pembelajaran pada siklus berikutnya. Adapun hasil refleksi tersebut adalah sebagai berikut:

Keterampilan guru selama pembelajaran pada siklus I pertemuan 1 secara keseluruhan sudah termasuk dalam kategori baik, namun masih ada beberapa hal yang perlu diperbaiki. Hal - hal yang perlu mendapatkan perbaikan yaitu: Dalam kegiatan pra pembelajaran, guru belum mengecek kehadiran siswa, Ketika membuka pelajaran, guru tidak menyampaikan kalimat motivasi untuk siswa dan menyampaikan tujuan pembelajaran.

Untuk keterampilan menyampaiakan materi, guru belum melaksanakan penyampaian materi pembelajaran secara runtut dari yang konkret ke yang abstrak. Pada keterampilan mengajukan pertanyaan, guru belum memindahkan giliran siswa untuk menjawab pertanyaan dan memberikan waktu untuk berpikir, bertanya dan menjawab. Ketika guru mengelola kelas untuk pembentukan kelompok, guru belum memberikan nama untuk masing-masing kelompok. Guru juga belum melaksanakan membimbing untuk semua kelompok dan menutup diskusi dengan meminta siswa membuat rangkuman hasil diskusi, pada keterampilan membimbing diskusi kelompok kecil. Pada keterampilan mengajar perseorangan atau kelompok juga tidak dilaksanakan kegiatan penguatan kepada siswa dan mengadakan pendekatan secara pribadi kepada siswa dengan sikap bersahabat. Adapun untuk keterampilan memberikan penguatan berupa penghargaan kelompok, guru belum memberikan pengautan dengan memberikan hadiah yang relevan dan rasional. Pada keterampilan mengadakan variasi pembelajaran, guru juga belum mengadakan pergantian posisi gerak di dalam kelas dan media pembelajar-an yang digunakan belum mampu memfasilitasi proses interaksi siswa dengan guru secara optimal. Untuk keterampilan menutup pelajaran, guru tidak melaksanakan kegiatan membuat rangkuman dan melaksanakan tindak lanjut.

Refleksi manifestasi minat siswa selama pembelajaran berlangsung pada siklus I pertemuan 1 secara keseluruhan sudah termasuk dalam kategori berminat, tetapi masih ada beberapa kekurangan yang harus diperbaiki. Kekurangan-kekurangan tersebut yaitu: 1) Beberapa siswa masih terlihat kurang menyiapkan diri untuk menerima pembelajaran. 2) Dalam apersepsi masih banyak siswa yang tidak merespon. 3) Banyak siswa yang tidak memiliki inisiatif untuk menanyakan sesuatu yang belum dipahami pada saat pembelajaran. Para siswa cenderung pasif. 4) Ketika penghargaan kelompok, ada beberapa siswa yang terlihat tidak 
1382 Upaya Meningkatkan Kualitas Pembelajaran Matematika Materi Geometri dengan Menggunakan Pembelajaran Kooperatif Tipe STAD di MIN Kota Jambi-Sopiah

DOI : https://doi.org/10.31004/basicedu.v5i3.929

menerima dan kurang tertib. 5) Siswa juga terlihat kurang menanggapi umpan balik yang diberikan guru pada saat refleksi pembelajaran.

Berdasarkan paparan hasil belajar siklus I pertemuan 1, rata-rata nilai yang diperoleh siswa sudah mencapai $K K M$ 60,00. Persebaran nilai yang diperoleh siswa juga sudah mulai merata. Namun demikian, jika dilihat dari persentase ketuntasan belajar yang diperoleh siswa, maka hasil belajar siswa masih belum memenuhi kriteria yang ditetapkan yaitu tuntas $75 \%$. Berdasarkan data hasil belajar siswa pada siklus I pertemuan 1 diketahui bahwa persentase ketuntasan belajar siswa hanya 59\%, yaitu siswa yang tuntas $K K M$ 60 hanya 19 siswa dari 32 siswa. Oleh karena itu, peneliti perlu melanjutkan pada siklus I pertemuan 2. Sesuai dengan tujuan penelitian, deskripsi observasi pada siklus I pertemuan 2 terdiri dari hasil observasi keterampilan guru, hasil observasi manifestasi minat siswa dan hasil belajar. Penjelasan untuk masing-masing bagian tersebut adalah sebagai berikut: 1) Hasil Observasi Manifestasi Minat Siswa Manifestasi minat siswa dalam proses pembelajaran Matematika materi geometri melalui model Pembelajaran Kooperatif Tipe STAD pada siklus I pertemuan 2, dapat disajikan seperti pada tabel berikut: 2) manifestasi minat siswa pada pembelajaran Matematika materi geometri melalui model pembelajaran kooperatif tipe STAD pada siklus I pertemuan 2 adalah 28,34 dengan skor rata-rata 2,83 dan persentase rata-rata mencapai 70,86.

Hasil data tersebut digolongkan dalam kategori berminat. Adapun penjelasan untuk masing-masing indikator adalah sebagai berikut: 3) Pada indikator mempersiapkan diri dalam pembelajaran, tiga siswa mendapatkan skor 1, empat belas siswa mendapatkan skor 2, tujuh siswa mendapatkan skor 3 dan delapan siswa mendapatkan skor 4. Adapun jumlah skor perolehan adalah 84 dan rata-rata 2,63 sehingga tergolong dalam kategori berminat. Untuk indikator menanggapi apersepsi guru, siswa tergolong dalam kategori berminat. Hal tersebut karena empat siswa mendapatkan skor 1, sepuluh siswa mendapatkan skor 2, tiga belas siswa mendapatkan skor 3 dan lima siswa yang mendapatkan skor 4, sehingga jumlah skor 83 dengan rata-rata 2,59. Adapun indikator konsentrasi menerima penjelasan guru, siswa yang memperoleh skor 1 sebanyak tiga siswa, skor 2 diperoleh sebelas siswa, skor 3 diperoleh empat belas siswa dan skor 4 diperoleh empat siswa dengan jumlah 83 dengan rata-rata 2,59 dan tergolong berminat. Indikator berinisiatif menanyakan sesuatu yang belum dipahami memperoleh skor terendah, karena hanya mendapatkan skor dengan jumlah 67 dengan rata-rata 2,09 dan tergolong cukup berminat, karena tiga belas siswa mendapatkan skor 1, tujuh siswa mendapatkan skor 2, delapan siswa mendapatkan skor 3 dan empat siswa yang mendapatkan skor 4 .

Segera melaksanakan tugas dalam pembentukan kelompok merupakan indikator berikutnya yang siswa tergolong berminat didalamnya, karena siswa yang mendapatkan skor 4 sebanyak tujuh belas siswa, sembilan siswa mendapatkan skor 3, dua siswa mendapatkan skor 2 dan empat siswa yang mendapat skor 1, sehingga jumlah skor 103 dan rata-rata skor 3,22. Untuk indikator dapat bekerjasama dalam kelompok, siswa tergolong berminat, terbukti dengan skor 4 diperoleh oleh empat belas siswa, skor 3 diperoleh oleh delapan siswa, skor 2 diperoleh oleh tujuh siswa dan skor 1 diperoleh oleh tiga siswa, sehingga jumlah skor 97 dan rata-rata 3,03. Bekerja keras dalam mengerjakan tugas kelompok merupakan indikator yang siswa tergolong berminat selanjutnya. Siswa yang memperoleh skor 4 adalah delapan belas siswa, tujuh siswa memperoleh skor 3, lima siswa memperoleh skor 2 dan dua siswa memperoleh skor 1 dengan perolehan skor 105 dan rata-rata 3,28. Teratur dalam mengerjakan evaluasi merupakan indikator yang mendapatkan skor tertinggi yaitu jumlah skor 113 dengan rata-rata 3,53 dan masih tergolong dalam kategori berminat. Skor tersebut diperoleh dari dua puluh satu siswa mendapatkan skor 4, tujuh siswa mendapatkan skor 3, empat siswa mendapatkan skor 2 dan tidak ada siswa yang mendapatkan skor 1.

Untuk indikator tertib dalam menerima penghargaan kelompok, siswa yang mendapatkan skor 1 adalah tiga siswa, skor 2 diperoleh tujuh siswa, skor 394 diperoleh delapan belas siswa dan skor 4 diperoleh empat siswa dengan jumlah 87 dan rata-rata 2,72 tergolong berminat. Menanggapi umpan balik dari guru sebagai bahan refleksi menjadi indikator terakhir yang siswa tergolong berminat di dalamnya karena empat siswa memperoleh skor 1, delapan siswa memperoleh skor 2, lima belas siswa memperoleh skor 3 dan lima siswa 
1383 Upaya Meningkatkan Kualitas Pembelajaran Matematika Materi Geometri dengan Menggunakan Pembelajaran Kooperatif Tipe STAD di MIN Kota Jambi-Sopiah

DOI : https://doi.org/10.31004/basicedu.v5i3.929

memperoleh skor 4 sehingga jumlah skor menjadi 85 dan rata-rata 2,66. Keadaan diatas menunjukkan bahwa telah terjadi peningkatan minat siswa dalam pembelajaran Matematika materi geometri melalui model pembelajaran kooperatif tipe STAD. Pernyataan tersebut juga didukung oleh hasil angket minat siswa yang terlampir dalam lampiran penelitian ini. Hasil angket minat siswa yang dilakukan prasiklus dan pascasiklus menunjukkan bahwa minat siswa mengalami peningkatan rata-rata skor sebesar 7,81 poin. Hal tersebut terjadi karena ada peningkatan rata-rata skor pada prasiklus dari 49,47 dengan kriteria cukup berminat, menjadi 57,28 dengan kriteria berminat pada pascasiklus.

Hasil belajar siswa dalam pembelajaran Matematika materi geometri melalui pembelajaran kooperatif tipe $S T A D$ pada siklus I pertemuan 2 dapat diketahui bahwa nilai tertinggi yang diperoleh siswa adalah 90 dan nilai terendah adalah 40 dengan rata-rata 63,125. Persentase ketuntasan hasil belajar siswa adalah $69 \%$, dan ketidaktuntasan hasil belajar siswa $31 \%$. Data tersebut menunjukkan peningkatan jika dibandingkan dengan nilai hasil belajar siswa pada siklus I pertemuan 1.

Refleksi pembelajaran geometri melalui model pembelajaran kooperatif tipe STAD pada siklus I pertemuan 2, difokuskan pada dua hal, yaitu: (1) keterampilan guru, dan (2) manifestasi minat siswa. Refleksi ini dipergunakan sebagai bahan pertimbangan untuk memperbaiki pembelajaran pada siklus berikutnya. Adapun hasil refleksi tersebut adalah sebagai berikut:

Refleksi manifestasi minat siswa selama pembelajaran berlangsung pada siklus I pertemuan 2 secara keseluruhan sudah masuk dalam kategori berminat, tetapi masih ada beberapa kekurangan yang harus diperbaiki. Kekurangan-kekurangan tersebut yaitu: a) Banyak siswa yang tidak memiliki inisiatif untuk menanyakan sesuatu yang belum dipahami pada saat pembelajaran, b) Ketika penghargaan kelompok, ada beberapa siswa yang terlihat tidak menerima dan kurang tertib, c) Siswa juga terlihat kurang menanggapi umpan balik yang diberikan guru pada saat refleksi pembelajaran.

Hasil pembelajaran geometri melalui model pembelajaran kooperatif tipe STAD pada siklus I pertemuan 2 menunjukkan bahwa secara keseluruhan siswa sudah mengalami ketuntasan dalam belajar, dengan rata-rata nilai yang diperoleh yaitu 63,125 . Nilai terendah yang diperoleh siswa adalah 40 dan nilai tertinggi yaitu 90 . Siswa yang memperoleh nilai tuntas $(\geq 60)$ sejumlah 22 orang atau $69 \%$, dan siswa yang memperoleh nilai tidak tuntas $(<60) 10$ orang atau 31\%. Berdasarkan data perbandingan hasil pretes dan hasil belajar siklus I dapat diketahui bahwa persentase ketuntasan belajar meningkat dari 37,5\% pada saat pretes, menjadi 59\% pada pertemuan 1 dan menjadi 69\% pada pertemuan 2. Namun peningkatan tersebut belum mencapai indikator keberhasilan yaitu $75 \%$. Oleh karena itu, peneliti perlu melanjutkan penelitian pada siklus II.

Berdasarkan hasil observasi keterampilan guru, dan manifestasi minat siswa dalam pembelajaran geometri melalui model pembelajaran kooperatif tipe STAD siklus I pertemuan 2, maka perlu diadakan perbaikan agar dapat meningkatkan kualitas pembelajaran. Perbaikan yang dimaksud antara lain: Manifestasi Minat Siwa Perbaikan pada aspek manifestasi minat siswa adalah sebagai berikut: a) Pada Banyak siswa yang tidak memiliki inisiatif untuk menanyakan sesuatu yang belum dipahami pada saat pembelajaran, b) Ketika penghargaan kelompok, ada beberapa siswa yang terlihat tidak menerima dan kurang tertib, c) Siswa juga terlihat kurang menanggapi umpan balik yang diberikan guru pada saat refleksi pembelajaran.

Sebagaimana siklus I, siklus II juga dilaksanakan dalam dua pertemuan. Adapun hasil pelaksanaannya dapat dijelaskan perpertemuan sebagai berikut: Diskripsi observasi pelaksanaan tindakan siklus II pertemuan 1 terdiri dari hasil observasi keterampilan guru, hasil observasi manifestasi minat siswa dan hasil belajar siswa. Penjelasan lebih rinci adalah sebagai berikut:

Minat siswa dalam proses pembelajaran Matematika materi geometri melalui Pembelajaran Kooperatif Tipe STAD pada siklus II pertemuan 1 diperolehjumlah skor 29,50 dengan skor rata-rata 2,95 dan persentase 
1384 Upaya Meningkatkan Kualitas Pembelajaran Matematika Materi Geometri dengan Menggunakan Pembelajaran Kooperatif Tipe STAD di MIN Kota Jambi-Sopiah

DOI : https://doi.org/10.31004/basicedu.v5i3.929

rata-rata mencapai 73,75 . Skor tersebut dapat digolongkan dalam kriteria berminat. Adapun penjelasannya adalah sebagai berikut:

Pada indikator mempersiapkan diri dalam pembelajaran, dua siswa mendapatkan skor 1, sepuluh siswa mendapatkan skor 2, sebelas siswa mendapatkan skor 3 dan sembilan siswa mendapatkan skor 4. Jumlah skor yang diperoleh menjadi 91 dengan rata-rata 2,84 sehingga tergolong dalam kriteria berminat.Untuk indikator menanggapi apersepsi guru, siswa tergolong dalam kriteria berminat karena jumlah skor yang diperoleh adalah 83 dengan rata-rata 2,59. Hasil tersebut diperoleh karena empat siswa mendapatkan skor 1, sepuluh siswa mendapatkan skor 2, tiga belas siswa mendapatkan skor 3 dan lima siswa mendapatkan skor 4.Adapun indikator konsentrasi menerima penjelasan guru tergolong dalam kriteria berminat. Hal tersebut karena siswa yang memperoleh skor 1 sebanyak tiga siswa, skor 2 diperoleh sepuluh siswa, skor 3 diperoleh lima belas siswa dan skor 4 diperoleh empat siswa, sehinggan jumlah skor 84 dengan rata-rata 2,63.

Indikator berinisiatif menanyakan sesuatu yang belum dipahami hanya mendapatkan jumlah skor 72 dengan rata-rata 2,25 dan tergolong dalam kriteria cukup berminat. Hal tersebut karena delapan siswa mendapatkan skor 1, dua belas siswa mendapatkan skor 2, delapan siswa mendapatkan skor 3 dan empat siswa mendapatkan skor 4.Dengan jumlah skor 104 dan rata-rata 3,25, indikator segera melaksanakan tugas dalam pembentukan kelompok tergolong dalam kriteria berminat. Hal tersebut karena siswa yang mendapatkan skor 4 sebanyak tujuh belas siswa, delapan siswa mendapatkan skor 3, lima siswa mendapatkan skor 2 dan dua siswa yang lain mendapat skor 1.

Untuk indikator dapat bekerjasama dalam kelompok, siswa tergolong berminat. Hal itu terbukti dengan skor 4 diperoleh oleh enam belas siswa, skor 3 diperoleh oleh tujuh siswa, skor 2 diperoleh oleh tujuh siswa dan skor 1 diperoleh hanya oleh dua siswa, sehingga jumlah skor 101 dan rata-rata 3,16.Bekerja keras dalam mengerjakan tugas kelompok merupakan indikator yang siswa tergolong berminat selanjutnya. Siswa yang memperoleh skor 4 adalah sembilan belas siswa, enam siswa memperoleh skor 3, lima siswa memperoleh skor 2 dan dua siswa memperoleh skor 1. Jumlah skor yang diperoleh adalah 106 dan rata-rata 3,31.

Teratur dalam mengerjakan evaluasi merupakan indikator yang mendapatkan skor tertinggi yaitu jumlah skor 116 dengan rata-rata 3,63 dan masih tergolong dalam kategori berminat. Skor tersebut diperoleh dari dua puluh dua siswa mendapatkan skor 4, delapan siswa mendapatkan skor 3, serta dua siswa mendapatkan skor 2 karena tidak ada siswa yang mendapatkan skor 1.Untuk indikator tertib dalam menerima penghargaan kelompok, siswa yang mendapatkan skor 1 adalah dua siswa, skor 2 diperoleh delapan siswa, skor 3 diperoleh tiga belas siswa dan skor 4 diperoleh sembilan siswa. Hal tersebut menyebabkan jumlah skor 93 dengan rata-rata 2,91 dan tergolong berminat 108. Menanggapi umpan balik dari guru sebagai bahan refleksi menjadi indikator terakhir yang siswa tergolong berminat didalamnya. Hal tersebut karena hanya dua siswa yang memperoleh skor 1, tujuh siswa memperoleh skor 2, empat belas siswa memperoleh skor 3 dan sembilan siswa memperoleh skor 4 sehingga jumlah skor 94 dan rata-rata 2,94.

Hasil belajar siswa dalam pembelajaran Matematika materi geometri melalui pembelajaran kooperatif tipe STAD dapat diketahui bahwa nilai tertinggi yang diperoleh siswa adalah 100 dan nilai terendah adalah 30 dengan rata-rata 65,625. Persentase ketuntasan hasil belajar siswa adalah 72\% yaitu diperoleh oleh 27 siswa. Sedangkan persentase ketidaktuntasan hasil belajar siswa adalah $28 \%$ yaitu diperoleh oleh 5 siswa.

Berdasarkan data tersebut dapat diketahui bahwa ada peningkatan nilai hasil belajar pada siklus II pertemuan 1 jika dibandingkan dengan nilai hasil belajar pada siklus I. Refleksi pembelajaran geometri melalui model pembelajaran kooperatif tipe $S T A D$ pada siklus II pertemuan 1, Adapun hasil refleksi tersebut adalah sebagai berikut:Refleksi manifestasi minat siswa selama pembelajaran berlangsung pada siklus II pertemuan 1 secara keseluruhan sudah masuk dalam kategori berminat, tetapi masih ada beberapa kekurangan yang harus diperbaiki. Kekurangan-kekurangan tersebut yaitu: a) Tercatat dua siswa masih terlihat tidak menyiapkan diri untuk menerima pembelajaran, b) Hanya lima siswa yang aktif merespon apersepsi 
1385 Upaya Meningkatkan Kualitas Pembelajaran Matematika Materi Geometri dengan Menggunakan Pembelajaran Kooperatif Tipe STAD di MIN Kota Jambi-Sopiah

DOI : https://doi.org/10.31004/basicedu.v5i3.929

yang diberikan guru, c) Banyak siswa yang tidak memiliki inisiatif untuk menanyakan sesuatu yang belum mereka pahami pada saat pembelajaran. Mereka cenderung pasif.

Hasil pembelajaran geometri melalui model pembelajaran kooperatif tipe STAD siklus II pertemuan 1, secara keseluruhan siswa sudah mengalami ketuntasan dalam belajar, dengan rata-rata nilai yang diperoleh yaitu 65,625. Nilai terendah yang diperoleh siswa yaitu 30 dan nilai tertinggi yaitu 100. Berdasarkan data tersebut dapat diketahui bahwa nilai yang diperoleh siswa sudah hampir merata, sehingga kesenjangan nilai antar siswa semakin berkurang. Siswa yang memperoleh nilai tuntas $(\geq 60)$ sejumlah 27 orang atau 59\%, dan siswa yang memperoleh nilai tidak tuntas $(<60) 5$ orang atau $28 \%$.

Melihat hasil observasi keterampilan guru, manifestasi minat siswa dalam pembelajaran geometri melalui model pembelajaran kooperatif tipe $S T A D$ siklus II pertemuan 1, maka perlu diadakan perbaikan agar dapat meningkatkan kualitas pembelajaran, perbaikan tersebut antara lain: Manifestasi Minat Siwa, a) Memberikan nasihat dan contoh kepada siswa untuk menyiapkan diri pada saat akan menerima pembelajaran, b) Memotivasi siswa untuk lebih merespon apersepsi guru dan berani bertanya, c) Menyajikan materi pembelajaran yang menarik dan memancing siswa untuk bertanya tentang sesuatu yang belum dipahami.

Pemaknaan temuan penelitian didasarkan atas hasil observasi keterampilan guru, manifestasi minat siswa dan hasil belajar siswa sebagai berikut : Pada siklus I pertemuan 1, rata-rata hasil observasi manifestasi minat siswa memperoleh skor 2,79 dengan kriteria berminat. Sedangkan pada siklus I pertemuan 2, rata-rata hasil observasi manifestasi minat siswa meningkat menjadi 2,84. Peningkatan ini terjadi karena pada pertemuan 1, sebagian siswa masih terlihat belum mempersiapkan diri untuk menerima pembelajaran. Hal tersebut terlihat dari tidak disiapkannya buku-buku dan alat tulis di meja. Disamping itu siswa terlihat pasif dalam menanggapi apersepsi guru, juga pasif dalam pembelajaran yang terlihat dari hampir tidak ada pertanyaan dari siswa yang muncul mengenai pembelajaran. Siswa juga belum dapat bekerja sama dengan baik dalam kelompok, yeng terlihat dari kurangnya interaksi dan masih adanya dominasi sedangkan yang lain cenderung diam. Demikian juga yang terjadi pada aspek menanggapi umpan balik dari guru sebagai bahan refleksi, siswa cenderung pasif dan hanya didominasi oleh beberapa siswa yang pandai, meskipun sudah lebih baik bila dibandingkan dengan awal pembelajaran.

Pada siklus I pertemuan 2, siswa sudah mulai aktif dalam pembelajaran, yang ditandai dengan semakin bertambahnya siswa yang bertanya, meskipun pertanyaan siswa masih perlu diarahkan ke materi pembelajaran. Namun demikian, siswa juga masih terlihat kurang siap dalam menerima materi pembelajaran yang ditandai dengan masih adanya siswa yang tidak mempersiapkan buku-buku dan alat tulis di meja. Disamping itu, konsentrasi. Siswa menjadi terganggu karena adanya pertanyaan-pertanyaan yang muncul yang belum mengarah kepada materi pembelajaran. Sehingga menimbulkan keriuhan ditengah penjelasan materi. Adapun pada saat bekerja kelompok, ada beberapa kelompok yang terlihat tidak saling bekerjasama yang terlihat dari pola duduk siswa. Hal tersebut berimbas pada penilaian indikator bekerja keras dalam mengerjakan tugas kelompok.

Pada siklus II pertemuan 1, rata-rata hasil observasi manifestasi minat siswa adalah 2,95 dengan kategori berminat, kemudian meningkat menjadi 3,19 pada siklus II pertemuan 2. Peningkatan tersebut terjadi karena pada pertemuan 1, masih ada siswa yang terlihat tidak mempersiapkan diri untuk menerima pembelajaran. Siswa juga cenderung pasif dalam pembelajaran terlihat dari sedikitnya pertanyaan yang muncul dalam pembelajaran dan masih didominasi oleh siswa-siswa pandai. Adapun pada siklus II pertemuan 2, hasil observasi manifestasi minat siswa menunjukkan hasil yang lebih baik dan sudah mencapai indikator yang telah ditentukan. Hal tersebut terjadi karena siswa melakukan berbagai macam aktivitas yang menjadi bentuk manifestasi minat siswa. Sebagaimana yang dikemukakan oleh Slameto (2010: 180) bahwa minat dapat dimanifestasikan melalui partisipasi dalam suatu aktivitas. Aktivitas yang terjadi dalam pembelajaran 
1386 Upaya Meningkatkan Kualitas Pembelajaran Matematika Materi Geometri dengan Menggunakan Pembelajaran Kooperatif Tipe STAD di MIN Kota Jambi-Sopiah

DOI : https://doi.org/10.31004/basicedu.v5i3.929

adalah berupa aktivitas fisik maupun psikis sebagaimana pendapat Douglass (dalam Hamalik, 2008: 172) bahwa suatu belajar diperoleh melalui berbagai macam aktivitas.

Rata-rata hasil belajar siswa dalam pembelajaran geometri melalui model pembelajaran kooperatif tipe STAD, mengalami peningkatan. Rata-rata nilai siswa meningkat dari siklus I sebesar 61,56 menjadi 69,22 pada siklus II. Persentase ketuntasan belajar individual siswa juga mengalami peningkatan dari $64 \%$ atau 20 dari 32 siswa pada siklus I menjadi $77 \%$ atau 25 dari 32 siswa pada siklus II. Berdasarkan data tersebut, pencapaian hasil belajar siswa pada siklus kedua sudah mencapai indikator keberhasilan yaitu $75 \%$ siswa mengalami ketuntasan belajar individual $\geq 60$.

Peningkatan nilai yang diraih siswa dalam pembelajaran Matematika materi geometri melalui model pembelajaran kooperatif tipe $S T A D$ ini merupakan suatu perubahan perilaku siswa dalam belajar matematika, sehingga siswa memperoleh hasil yang lebih baik sebagai suatu hasil belajar(Bungsu et al., 2020). Pendapat tersebut didukung oleh (Murtiyasa \& Hapsari, 2020) yang mengemukakan bahwa hasil belajar merupakan perilaku yang diperoleh pebelajar setelah mengalami kegiatan belajar. Dalam pembelajaran, perubahan tingkah laku yang harus dicapai oleh pelajar setelah melaksanakan kegiatan belajar dirumuskan dalam tujuan pembelajaran.

Dalam penelitian yang telah dilakukan, terlihat bahwa terjadi peningkatan keterampilan guru, minat siswa, dan hasil belajar. Hal ini dapat membuktikan bahwa model pembelajaran kooperatif tipe STAD dapat meningkatkan kualitas dalam proses pembelajaran, terutama pembelajaran Matematika materi geometri.

Melalui penggunaan model pembelajaran kooperatif tipe $S T A D$, guru selain dapat mengelola proses pembelajaran dengan baik, juga menjadi lebih terampil terutama dalam mengarahkan siswa (Sri Fatoyah et al., 2020). Selain itu, siswa menjadi lebih aktif dan dapat melatih kemampuan sosial untuk bekerjasama dalam proses pembelajaran, sehingga proses pembelajaran dapat berjalan dengan optimal dan mengurangi kesenjangan antara siswa dalam belajar serta meningkatkan minat siswa dalam pembelajaran.

Dalam pembelajaran terjadi interaksi dua arah antara guru dan siswa. Pada saat guru menjelaskan materi geometri, siswa memperhatikan dengan seksama dan guru memberikan kesempatan siswa untuk bertanya. Pada saat siswa mengerjakan LKK, guru memberikan bimbingan dan mengarahkan siswa untuk berpendapat dan berinteraksi baik antarsiswa maupun antara siswa dengan guru. Hal ini menunjukan bahwa pembelajaran tidak hanya berpusat pada guru saja, akan tetapi guru berperan sebagai fasilitator yang membantu siswa dalam proses pembelajaran agar berjalan dengan baik.

Dengan penggunaan pembelajaran kooperatif tipe $S T A D$, siswa lebih berminat dalam pembelajaran, dan guru juga lebih mudah mengajarkan materi pelajaran disamping juga meningkatkan hasil belajar (Kadir, 2020). Hal ini menunjukkan bahwa terjadi peningkatan kualitas pembelajaran Matematika khususnya materi geometri. Oleh karena itu, penelitian ini diharapakan dapat dikembangkan lebih lanjut, baik oleh guru maupun oleh pengembang lainnya. Hal ini sejalan pembelajaran kooperatif tipe STAD dapat menjadi lebih baik dan kriteria pembelajaran dapat tercapai.

\section{KESIMPULAN}

Berdasarkan hasil penelitian yang dilakukan terhadap keterampilan guru,minat siswa dan hasil belajar siswa pada pembelajaran Matematika materi geometri melalui model pembelajaran kooperatif tipe STAD, peneliti dapat menarik kesimpulan, bahawa pembelajaran kooperatif tipe STAD dapat meningkatkan keterampilan guru dalam pembelajaran Matematika materi geometri pada siswa kelas IV Madrasah Ibtidaiyah Negeri Kota Jambi . Pada siklus I pertemuan 1 diperoleh jumlah skor 25 dengan kategori baik kemudian pada siklus I pertemuan 2 diperoleh jum-lah skor 31 dengan kategori sangat baik. Sedangkan pada siklus II pertemu-an 1 diperoleh jumlah skor 35 dengan kategori sangat baik dan pada siklus II pertemuan 2 diperoleh skor 38 dengan kategori sangat baik. Rata-rata ha-sil observasi keterampilan guru pada siklus I adalah 28, 
1387 Upaya Meningkatkan Kualitas Pembelajaran Matematika Materi Geometri dengan Menggunakan Pembelajaran Kooperatif Tipe STAD di MIN Kota Jambi-Sopiah

DOI : https://doi.org/10.31004/basicedu.v5i3.929

sedangkan rata-rata pada siklus II adalah 36,5 sehingga terjadi peningkatan rata-rata keterampi-lan guru sebanyak 8,5 poin.

Pembelajaran kooperatif tipe STAD dapat meningkatkan minat siswa kelas IV Madrasah Ibtidaiyah Negeri Kota Jambi dalam pembelajaran Matematika materi geometri. Pada siklus I pertemuan 1 diperoleh rata - rata skor2,79 dengan kateGori berminat, sedangkan pada pertemuan 2 terjadi peningkatan menjadi 2,83. Pada siklus II pertemuan I diperoleh jumlah skor 2,95 dengan kategori berminat menjadi 3,19 pada pertemuan 2. Rata-rata hasil observasi manifes-tasi minat siswa pada siklus I adalah 2,81, sedangkan rata-rata pada siklus II adalah 3,07, sehingga telah terjadi peningkatan sebanyak 0,26 poin.

Pembelajaran kooperatif STAD dapat meningkatkan hasil belajar sis-wa kelas IV Madrasah Ibtidaiyah Negeri Kota Jambi dalam pembelajaran Matematika materi geometri. Rata-rata hasil belajar pada siklus I pertemuan 1 adalah 60,00 menjadi 63,125 pada pertemuan kemudian pada siklus II pertemuan 1 naik menjadi 65,625 dan naik lagi menjadi 72,8125 pada siklus 2. Sedang-kan untuk persentase ketuntasan belajar naik dari $59 \%$ pada siklus I pertemuan 1 menjadi $69 \%$ pertemuan 2 kemudian pada pertemuan II siklus 1 naik menjadi $72 \%$ dan naik lagi menjadi $81 \%$ pada siklus II pertemuan 2. Pada siklus I diperoleh nilai rata-rata 61,56 dan rata-rata ketuntasan belajar klasikal mencapai $64 \%$ yaitu sebanyak 20 dari 32 siswa. Pada siklus II di-peroleh nilai rata-rata hasil belajar 69,22 dengan rata-rata ketuntasan klasi-kal sebesar 77\% yaitu 25 dari 32 siswa.

\section{DAFTAR PUSTAKA}

Boliti, S. (2009). Peningkatan Kemampuan Membaca Pemahaman Siswa Kelas IV SDN 1 Lumbi-Lumbia Melalui Metode Latihan Terbimbing. Jurnal Kreatif Tadulako Online, 2(2).

Bungsu, T. K., Vilardi, M., Akbar, P., \& Bernard, M. (2020). Pengaruh Kemandirian Belajar Terhadap Hasil Belajar Matematika Di Smkn 1 Cihampelas. Journal On Education, 3(1).

Dewi, S. M., Prawiyogi, A. G., Anwar, A. S., \& Wahyuni, C. S. (2021). Efektivitas Strategi Direct Reading Thingking Activities terhadap Peningkatan Kemampuan Membaca Pemahaman Di Sekolah Dasar. Jurnal Basicedu, 5(1), 453-455. https://doi.org/10.31004/basicedu.v5i1.786

Fadhilaturrahmi. (2017). Peningkatan Hasil Belajar Siswa Pada Materi Jaring-jaring Balok dan Kubus dengan Pendekatan CTL siswa Kelas IV SDN 05 Air Tawar Barat PENINGKATAN HASIL BELAJAR SISWA PADA MATERI JARING-JARING BALOK DAN KUBUS DENGAN PENDEKATAN CONTEXTUAL TEACHING AND LEARN (Vol. 1). http://stkiptam.ac.id/indeks.php/basicedu

Fakhri, M., Taufik, M., \& Ismail, A. D. (2020). Improvement of Mathematics Learning Outcomes by Applying The Missouri Mathematics Project Learning Model And Dienes Game Theory. Mathematics Education Journal, 4(1). https://doi.org/10.22219/mej.v4i1.11474

Hendrayani, A. (2018). Peningkatan Minat Baca Dan Kemampuan Membaca Peserta Didik Kelas Rendah Melalui Penggunaan Reading Corner. Jurnal Penelitian Pendidikan, 17(3), 235-248.

Jamaluddin, J. (2020). Guru Sebagai Profesi. Jurnal Al-Qalam: Jurnal Kajian Islam \& Pendidikan, 6(1). https://doi.org/10.47435/al-qalam.v6i1.119

Kadir, D. (2020). Upaya Meningkatkan Kemampuan Membaca Permulaan Pada Siswa Kelas 1 SDN 05 Wanggarasi Tahun 2014/2015 Melalui Media Gambar. Aksara: Jurnal Ilmu Pendidikan Nonformal, 5(2). https://doi.org/10.37905/aksara.5.2.93-102.2019

Kamil, I., \& Kashardi, K. (2020). HASIL BELAJAR KOGNITIF SISWA MELALUI MODEL PEMBELAJARAN KOOPERATIF TIPE AIR DAN NHT. Jurnal Math-UMB.EDU, 7(3). https://doi.org/10.36085/math-umb.edu.v7i3.1056

Khotimah, S., \& Sari, E. N. (2018). Perbedaan Efektivitas Metode Peer Education Dan Media Audio Visual Terhadap Pengetahuan Dan Persepsi Remaja Mengenai Seks Pranikah. JOMIS (Journal Of Midwifery Science), 2(1), 26-31. https://doi.org/10.1002/pssc.200778518 
1388 Upaya Meningkatkan Kualitas Pembelajaran Matematika Materi Geometri dengan Menggunakan Pembelajaran Kooperatif Tipe STAD di MIN Kota Jambi-Sopiah

DOI : https://doi.org/10.31004/basicedu.v5i3.929

Lin, W., Yin, H., Han, J., \& Han, J. (2020). Teacher-student interaction and chinese students' mathematics learning outcomes: The mediation of mathematics achievement emotions. International Journal of Environmental Research and Public Health, 17(13). https://doi.org/10.3390/ijerph17134742

Murtiyasa, B., \& Hapsari, S. N. (2020). The Effect of TAI and STAD Strategy towards Learning Outcomes Reviewed from Mathematical Communication Skill. Universal Journal of Educational Research, 8(6). https://doi.org/10.13189/ujer.2020.080625

Sodiq, A. N., \& Trisniawati, T. (2020). Peningkatan Minat dan Hasil Belajar Matematika melalui Model Cooperative Learning Tipe Team Games Tournament pada Siswa SD Negeri Tukangan Yogyakarta. AlphaMath: Journal of Mathematics Education, 6(1). https://doi.org/10.30595/alphamath.v6i1.7738

Sri Fatoyah, Nayazik, A., \& Wahyuni, A. (2020). STUDI KOMPARASI HASIL BELAJAR MATEMATIKA MENGGUNAKAN MODEL PEMBELAJARAN KOOPERATIF TIPE NUMBERED HEADS TOGETHER (NHT) DAN STUDENT TEAMS ACHIEVEMENT DIVISION (STAD). Al-Qalasadi : Jurnal Ilmiah Pendidikan Matematika, 4(1). https://doi.org/10.32505/v3i2.1196

Syarif Sumantri, M., \& Satriani, R. (2016). The Effect of Formative Testing and Self-Directed Learning on Mathematics Learning Outcomes. In International Electronic Journal of Elementary Education (Vol. 8, Issue 3). www.simdik.info/hasilun/index.aspx. 